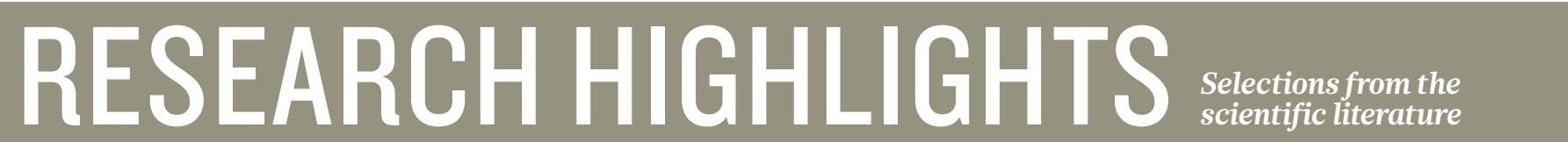

NEUROSCIENCE

\section{Cell transplants stem seizures}

Stem-cell therapy can reduce seizures in epileptic mice.

Some forms of epilepsy are thought to be caused by dysfunctional cells in the hippocampus region of the brain. The affected cells, called inhibitory interneurons, help to regulate neural circuits. Robert Hunt, Scott Baraban and their colleagues at the University of California, San Francisco, harvested progenitors of inhibitory neurons from embryonic mice and injected them into the hippocampi of epileptic adult mice.

In the brain, the cells matured into functioning inhibitory interneurons. Mice that received cell transplants had many fewer seizures than untreated mice. The transplants also reversed some behavioural problems that epileptic mice often develop, such as hyperactivity and poor spatial learning.

Nature Neurosci. http://dx.doi. org/10.1038/nn.3392 (2013)

\section{ADDICTION RESEARCH}

\section{Drug vaccine blocks rat relapse}

A vaccine stops heroinaddicted rats from seeking the drug.

Earlier vaccines against heroin have faltered because the antibodies that they induce are easily overwhelmed by increased doses of the drug. Joel Schlosburg and his colleagues at the Scripps Research Institute in La Jolla, California, have created a three-in-one vaccine: the antibodies it triggers target not only heroin, but also two of the drug's breakdown products. Active molecules are bound up by the antibodies

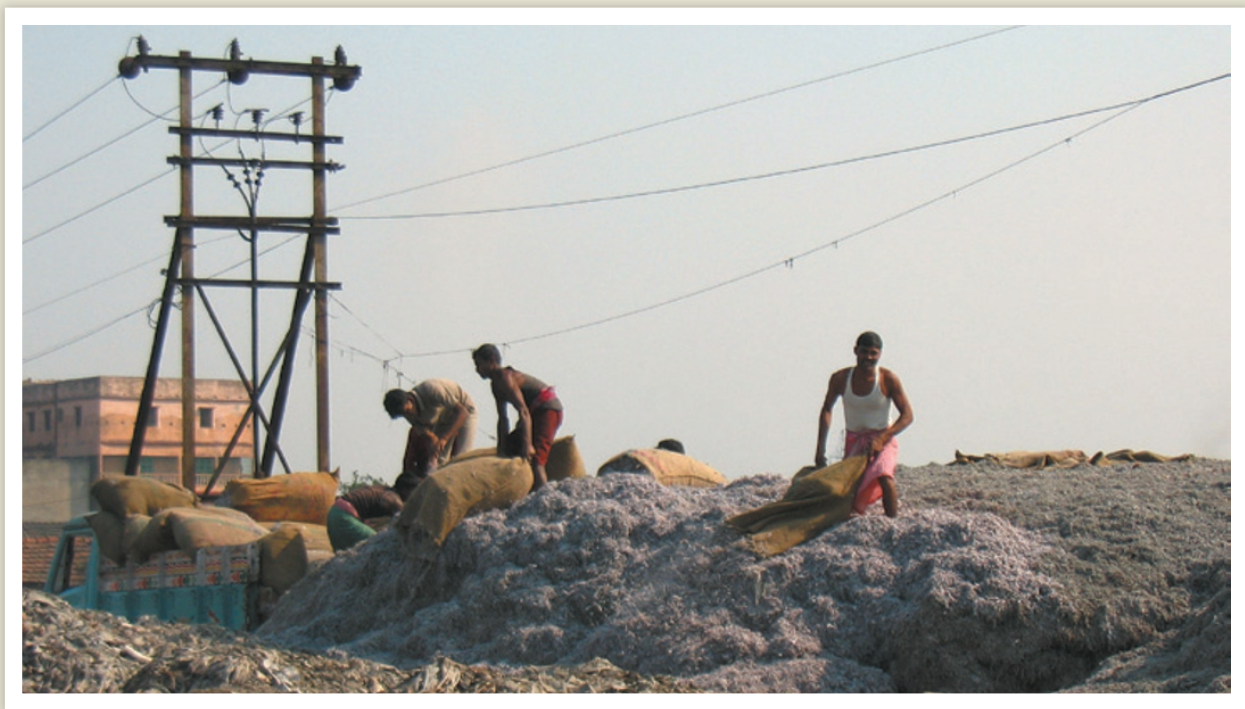

EPIDEMIOLOGY

\section{Unappreciated toll of toxic sites}

Toxic-waste sites pose as big a health threat as malaria in some developing nations.

Kevin Chatham-Stephens at the Icahn School of Medicine at Mount Sinai in New York and his colleagues produced a systematic assessment of the disease burden of toxic-waste sites in India (pictured), Indonesia and the Philippines.

The team used site visits, sampling, interviews and a global database of dumps to estimate that, in 2010, 8.6 million people were at risk of exposure to industrial pollutants - mainly lead and hexavalent chromium - at 373 sites in these nations. The authors calculated that the toxic exposures from just the surveyed sites resulted in the loss of more than 800,000 years of healthy life owing to ill-health and death in these countries, a toll about half that of air pollution and slightly more than that of malaria.

Environ. Health Perspect. http://dx.doi.org/10.1289/ ehp.1206127 (2013) before they can slip from the bloodstream into the brain. Vaccinated rats given heroin did not exhibit the compulsive drug-seeking behaviours seen in unvaccinated rats.

Proc. Natl Acad. Sci. USA

http://dx.doi.org/10.1073/

pnas.1219159110 (2013)

\section{CLIMATE SCIENCE}

\section{More cyclones for} Hawaitian Islands

Climate change could double the number of tropical cyclones that storm into the Hawaiian Islands.

Hiroyuki Murakami, then at the Meteorological Research
Institute in Tsukuba, Japan, and his colleagues simulated tropical-cyclone patterns using several versions of a weather model, as well as predictions of sea-surface warming. The authors used the simulations, which they verified against modern observations, to predict that the frequency of cyclones reaching the Hawaiian Islands during 2075-99 will be about double that in 1979-2003.

The change is due mainly to the way in which cyclones that arise off the west coast of Mexico are expected to move across the Pacific Ocean as the climate warms. Although fewer storms will form, more will take a path towards the islands and have enough power to reach them. Nature Clim. Change http://dx.doi.org/10.1038/ nclimate1890 (2013)

\section{MICROBIOLOGY}

\section{Fast life in the urinary tract}

Bacteria responsible for recurrent urinary-tract infections migrate from the gut.

These infections, which affect up to one-quarter of women, are caused mostly by strains of the bacterium Escherichia coli that are thought to give up their 